\title{
Raynaud's Phenomenon Impact on Quotidian Quality of Life
}

$\underline{\text { https://doi.org/10.3991/ijoe.v16i09.13993 }}$

\author{
Isobel Taylor, Ivone Silva, Susana Barreto, César Soares, \\ Joaquim Mendes $(\bowtie)$ \\ University of Porto, Porto, Portugal \\ jgabrielefe.up.pt
}

\begin{abstract}
Objective: To gain further understanding into the needs of Raynaud's phenomenon (RP), patient questionnaires were conducted in England, UK 2017 at an SRUK patient conference and Porto, Portugal 2018 at Central Hospital Universitário Porto (CHUP). The questions focused on daily activities and experience. Method: Sixty-four participants answered questions on their daily experience with RP, specific and general. Analysis grouped results into topics quantified by number and \%. Results: Although many tasks trigger RP episodes, some are more problematic than others, e.g. peeling vegetables; for many, the pain $(46.9 \%)$ is not the worst part, but instead the hinderance in function, inability (73.4\%) especially regarding hands and fingers. Conclusion: A Design Specification (DS) criterion for RP patients' hands is formed through the listed activities. The key needs identified for RP patients fingers and hands are maintenance of: Dexterity, Tactility and Comfort whilst cohering to aesthetic needs \& wellbeing.
\end{abstract}

Keywords - Design research, Patient Centred Design (PCD), Raynaud's phenomenon, wellbeing.

\section{Introduction}

\subsection{Quotidian quality of life and raynaud's phenomenon}

Raynaud's phenomenon (RP) causes sufferers daily struggle, therefore, has a strong impact on Quotidian Quality of Life (Q-QoL). By means of Design research methodologies, this paper assesses RP needs through patient questionnaire evaluation.

RP is denoted by periodic vasospasm in the blood vessels of the extremities (temporarily restricting blood flow) referred to as episodes or attacks that affects mainly fingers and toes. RP can be identifiable by episodic colour change, white, blue and red respectively, and history taken by a Medical Doctor (MD) [1]. RP is classified as either Primary or Secondary; Primary Raynaud's phenomenon (PRP) is idiopathic, Secondary Raynaud's phenomenon (SRP) is a symptom of an underlying condition [1,2].RP global prevalence is commonly published as $5-20 \%[3-5]$.For a clinical overview on RP, Herrick presents a thorough review of the state of Raynaud's phenomenon in medicine and research 2019 [6]. RP episodes vary in length, time, and severity. SRP patients can 
experience more severe symptoms than PRP patients; symptoms include, but are not limited to, pain \& numbness. RP episodes can be triggered by temperature change and/or emotional stress. Normal daily activities can trigger episodes, which can cause a huge impact on daily lives and this leaves a need for help to alleviate the difficulties/impact. A comprehensive understanding of what these struggles are is required for a tailored solution. Current treatment options are problematic as they tend to involve systematic adverse effects or have limited beneficial effects, a local approach is seen to be the optimal basis for a solution [7]. Pauling et al., conducted a multinational study on patient experience of SRP; Systematic Sclerosis (SSc) RP patients, from a medical perspective looking at Patient Reported Outcome instruments [8]. Pauling et al.'s study presents a similar exploration of experience but for a clinical need whilst this study is a design-led multidisciplinary needs identification study, design-engineering-medicine. This study aims to develop a Design Specification criteria base to facilitate exploration and development of local solutions. This paper is presented in 3 parts: Methods, Results $\&$ Discussion. Materials and methods look at the pool of participants involved, demographics, and the study design.

\section{Materials and Methods}

This study is conducted as research through design; methods include questionnaires, coding (topics tallied) and analysis. This study holds patients as the most important, which follows that the appropriate position is Patient Centred Design (PCD) $[9,10]$.

The sample is composed of 64 patients, aged 19 years old and above, all were presented with a document explaining the study and signed the informed consent. Ethical approval was granted by Universidade do Porto for both studies \& for Porto by Central Hospital Universitário Porto (CHUP), Ethics Ref: 2017.187(160-DEFI/152-CES). In the UK patients were recruited among SRUK participants on a voluntary basis; in Portugal, patients were pre recruited from the Hospital Database, informed and attended specifically for the purpose of taking part in the study, Table 1, Figures $1 \& 2$ outline the demographics.

\subsection{Study design}

Questionnaires were utilised in this study to gain qualitative insight. Questions were written open-ended encouraging explanations, elaborations and stories to build a picture of a complex circumstance, quotidian life with RP. The questionnaires were conducted at 2 locations; first at the 2017 SRUK patient conference day, UK; second replicated in Portuguese as part of a study in Porto, Portugal 2018. Both questionnaire results are included here to compare and reinforce findings. The questionnaires were taken in different venues, both geo-location and situationally, described in sections 1.2 $\& 1.3$ to show the collection of participants are not from equivalent pools and to build the understanding of who participated aside from the demographic information. 
The Design Specification (DS) will be formed though the questionnaire responses. The DS will form a checklist for a modification of a Product Design Specification (PDS) assessment [11], a list of requirements to ensure any solution meets the needs.

\subsection{SRUK scleroderma \& raynaud's UK charity}

Scleroderma \& Raynaud's UK (SRUK) is a UK charity dedicated to these patients. The charity has a website, social media, contacts for local groups and annual conferences. The conferences are attended by patients, friends and family, presented by MD's, researchers and advocates giving talks and available for questions [12]. During the annual conferences, from experience of attending in 2015, ' 16 and '17, there are market stalls, various main and breakout sessions and socialization opportunities. During breaks in activities socializing is encouraged with a very friendly atmosphere.

Audience: Attendance comprises of SRUK members predominately from the UK and Europe, those who travel further to attend may be motivated to do so, reflecting the difference in the participation groups between the questionnaires conducted in the UK and Portugal. The UK questionnaire was taken at the 2017 September 16th SRUK patient conference day in Crewe, England, UK.

\subsection{Clinical environment, Portugal}

The questionnaire was translated to Portuguese and conducted within a study in Porto, Portugal 2018, results were then translated to English for assessment. The Portuguese questionnaires were taken verbally in a research room, where more detailed responses were potentially achievable. Both results are included together to highlight the Quality of Life (QoL) impact. Table 1 \& Figures $1 \& 2$ show the differences between the 2 questionnaires taken regarding: geographic locations, time frame, demographics, affected anatomy and occupations. The questionnaire in Portugal was taken at Central Hospital Universitario Porto (CHUP), Portugal, March - June 2018.

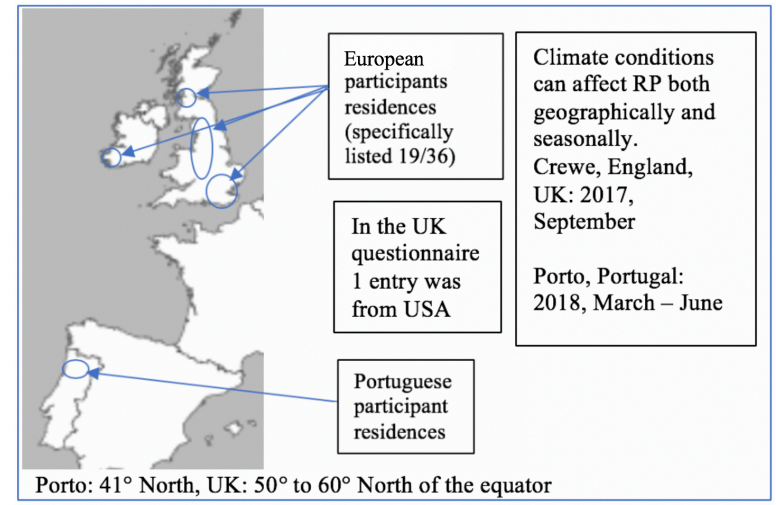

Fig. 1. Locations of UK \& Portugal participants. 
Table 1. Demographics

\begin{tabular}{|c|c|c|c|c|}
\hline \multicolumn{2}{|c|}{ Location questionnaire was taken } & UK & Portugal & Combined \\
\hline \multicolumn{2}{|c|}{ Participant numbers } & 36 & 28 & 64 \\
\hline \multicolumn{2}{|c|}{ Age, mean [SD] } & $58.9[10.8]$ & $48.6[16.1]$ & $54.4[14.3]$ \\
\hline \multicolumn{2}{|c|}{ RP classification } & n. $(\%)$ & n. $(\%)$ & n. $(\%)$ \\
\hline \multirow{4}{*}{ SRP } & $\mathrm{lcSSc}$ & $7(19.4)$ & $15(53.6)$ & $22(34.4)$ \\
\hline & $\mathrm{dcSSc}$ & $10(27.7)$ & $5(74.9)$ & $15(23.4)$ \\
\hline & $\mathrm{SSc}^{*}$ & $10(27.7)$ & $0(0)$ & $10(15.6)$ \\
\hline & Other & $8(22.2)$ & $2(7.1)$ & $10(15.6)$ \\
\hline \multicolumn{2}{|l|}{ PRP } & $1(2.7)$ & $6(21.4)$ & $7(10.9)$ \\
\hline \multicolumn{5}{|l|}{ Sex } \\
\hline \multicolumn{2}{|c|}{ Female } & $25(69.4)$ & $25(89.3)$ & $50(78.1)$ \\
\hline \multicolumn{2}{|c|}{ Male } & $2(5.5)$ & $3(10.7)$ & $5(7.8)$ \\
\hline \multicolumn{2}{|c|}{ Unknown } & $9(25)$ & $0(0)$ & $9(14.1)$ \\
\hline \multicolumn{5}{|c|}{ Occupation } \\
\hline \multicolumn{2}{|c|}{ Retired } & $17(47.2)$ & $4(14.3)$ & $21(32.8)$ \\
\hline \multicolumn{2}{|c|}{ Counsellor/ support worker } & $4(11.1)$ & 0 & $4(6.3)$ \\
\hline \multicolumn{2}{|c|}{ Manager } & $6(16.6)$ & 0 & $6(9.4)$ \\
\hline \multicolumn{2}{|c|}{ Office } & $1(2.7)$ & $3(10.7)$ & $4(6.3)$ \\
\hline \multicolumn{2}{|c|}{ Domestic/ home maker } & $1(2.7)$ & $6(21.4)$ & $7(10.9)$ \\
\hline \multicolumn{2}{|c|}{ Academia: [teacher or student] } & $1(2.7)$ & $6(21.4)$ & $6(9.4)$ \\
\hline \multicolumn{2}{|c|}{$\begin{array}{l}\text { Factory, shop work, seamstress, } \\
\text { butcher, cleaner }\end{array}$} & $1(2.7)$ & $7(25)$ & $8(12.5)$ \\
\hline \multicolumn{2}{|c|}{$\begin{array}{l}\text { Other: [UK Inc. farmer, taxi driver, au- } \\
\text { thor, medical. Portugal Inc. } \\
\text { MD/medical] }\end{array}$} & $5(13.8)$ & $2(7.1)$ & $7(10.9)$ \\
\hline
\end{tabular}

SSc: systemic sclerosis, lcSSc: limited cutaneous systemic sclerosis, dcSSc: diffuse cutaneous systemic sclerosis

* SSc condition unlisted

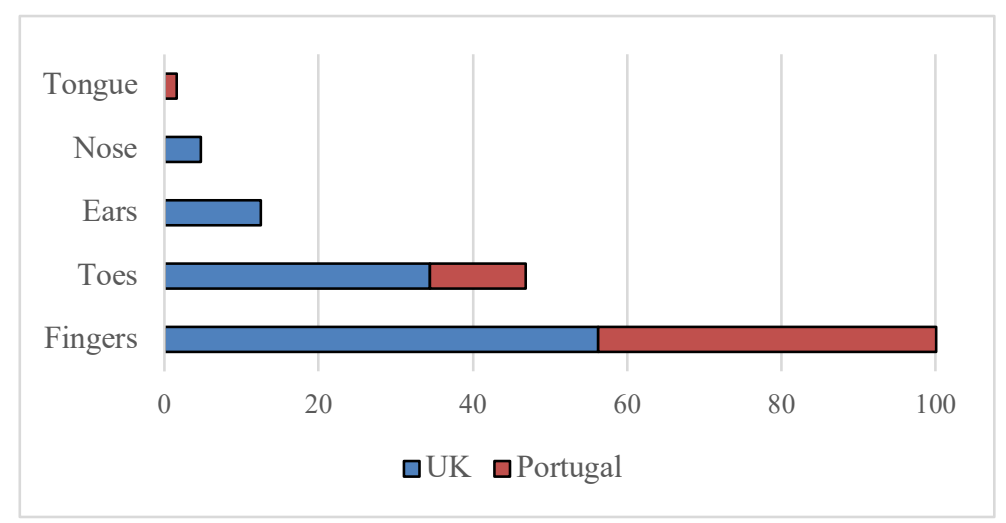

Fig. 2. Anatomy affected, UK \& Portugal, in \%. 


\subsection{Questionnaire}

The questionnaires are formed into 3 sections: A) Demographic information; age, conditions, locations, etc. B) Questions about a specific recent attack. C) Questions about attacks in general/ throughout the years. The questionnaire format was reviewed and translated for the Portuguese study containing all 3 sections above providing comparable answers.

\subsection{Data analysis}

The analysis of the responses on RP impact are broken into 4 sections, Table 2 Activities, Figure 4 - 'how often do you get attacks?', Table 3 - 'what do you do?', and Table 4 - 'what's the worst part?'. The responses were reviewed and grouped into central topics, tallies were taken on matching responses, these were then formed into themes. Questionnaires were then reviewed, a point/tally given to each theme the response fitted, participants were encouraged to give multiple responses. For each section and subsection quotes were added to bring back the humanity to the data and give details to the overall picture the study paints of the Q-QoL impact. The aim is to identify the themes and find the topics that have the highest impact. The questionnaire responses were analysed and identified by the author, who was also present in both locations. This study is subjective and unblinded.

\section{Results}

Demographics: Sixty-four patients participated in 2 locations from a total of 4 countries. Questionnaires taken in the UK totalled 36; of these participants locations were listed as: UK 34, Ireland $1 \&$ USA 1. Of the 34 from the UK, 18 listed specific locations as shown in Figure 1, the remaining 16 are listed as UK. Questionnaires taken in Portugal totalled 28, all from districts in the north of Portugal surrounding and including Porto, where the questionnaires were conducted, Figure 1. The average (mean) age of the combined 64 participants is $54.4,78.1 \%$ are listed as female and $73.4 \%$ have SSc, Table 1. The varieties of occupations build pieces towards a picture of the participants daily lives and give an impression of the participants who took part from each location, Table 1. Affected anatomy, quotes from Tables $2 \& 4$ show there are many references to hands and fingers, Figure 2 shows that every participant listed fingers, whilst in Portugal $28.6 \%$ participants listed toes and 3.6\% listed tongue, UK participants listed toes, ears and nose involvement $91.7 \%$. Table $2 \&$ Figure 4 shows what's triggering RP episodes and how often this occurs, whilst Tables $3 \& 4$ look at what people do when they have an RP episode and what is the worst part of these occurrences. Together these tables draw out patients' quotidian experiences. Figures $3,5 \& 6$ visualise the main reported problems of Tables $2,3 \& 4$, comparing the combined results of the topics. 


\subsection{RP triggers by activities}

The 'Activities', Table 2 \& Figure 3, enquire into locations and specific activities, UK and Portugal combined list 'at home' as the highest trigger location with 73.4\%. Second is 'Travel' $68.8 \%$ with the subgroup 'driving and walking' $43.8 \%$ (UK 55.6\%, PT 28.6\%). The next highest is home subgroup 'kitchen', 59.4\% (UK 63.9\%, PT $53.6 \%$ ). Third is 'other', $50 \%$, this shows the complexity in the specific problems to individuals. Fourth 'A/C (Air Conditioning), supermarkets' \& shopping 45.3\%, followed by fifth 'work' at $29.7 \%$. These top 5 outline basic requirements for life; to be able to go to shops \& locations with A/C, to prepare food, to work \& commute by foot, public transport or by car. This highlights activities that could be overlooked, walking outside is a common occurrence, as is driving, yet many find these problematic. This indicates towards the absolute frustration of facing quotidian activities when struggling with RP. Further to the topics listed 'grip/ holding things' was referred to by $68.8 \%$.

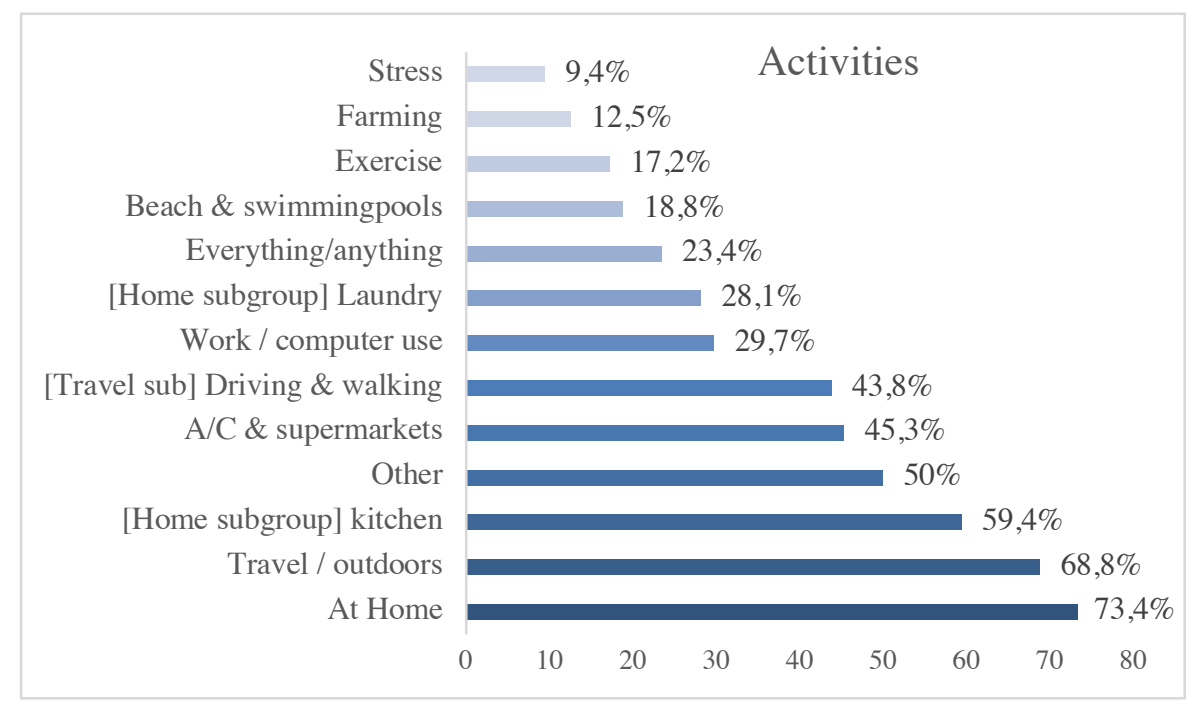

Fig. 3. Activities \& locations that trigger episodes/attacks of RP Triggers.

\subsection{Frequency of episodes}

Many of the UK and Portugal questionnaire participants experience RP episodes daily (48.4\%), when reviewing the triggers such as kitchen related tasks, this is understandable. Similarly, when asked if the effect is all year round or seasonal, the highest by both locations was all year round (64.1\%), Figure 4 is visualised by combined $\%$ response. 


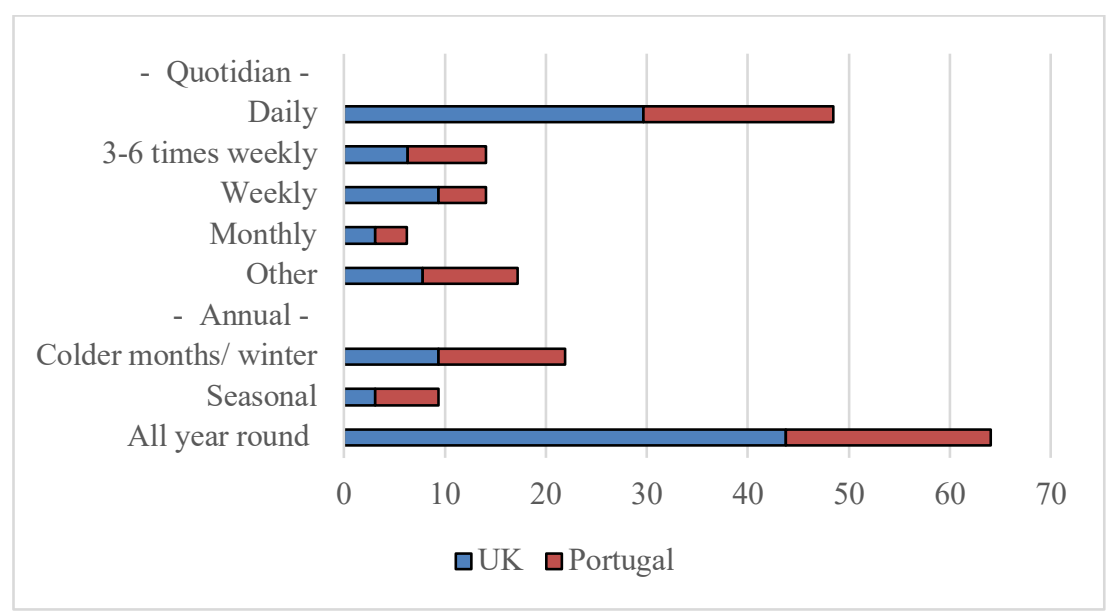

Fig. 4. Frequency of episodes by quotidian and annually, UK and Portugal, in $\%$.

\subsection{Response to episodes}

Both locations list Heat (51.6\%) as the top response to episodes, Table $3 \&$ Figure 5. Gloves $(50 \%)$ come second, however, many added extra comments to say that gloves don't help much, or they dislike using them, e.g. "Gets attacks with laundry, dislikes gloves, feels unable to function..." (Table 3, Gloves, Portugal), "The boss didn't allow the wearing of gloves in work, so gloves weren't worn" (Table 2, work, Portugal) and “... wears thin gloves, its painful, makes the job difficult.' (Table 4, inability, Portugal). Third is Rubbing, $4^{\text {th }}$ Other, $5^{\text {th }}$ hands to the body, Figure 5. The majority of these involve specific heat, be that from using core body heat, hot drinks, layers of clothing and/or gloves. Fewer comments were given in response to Table 3 than Table 2.

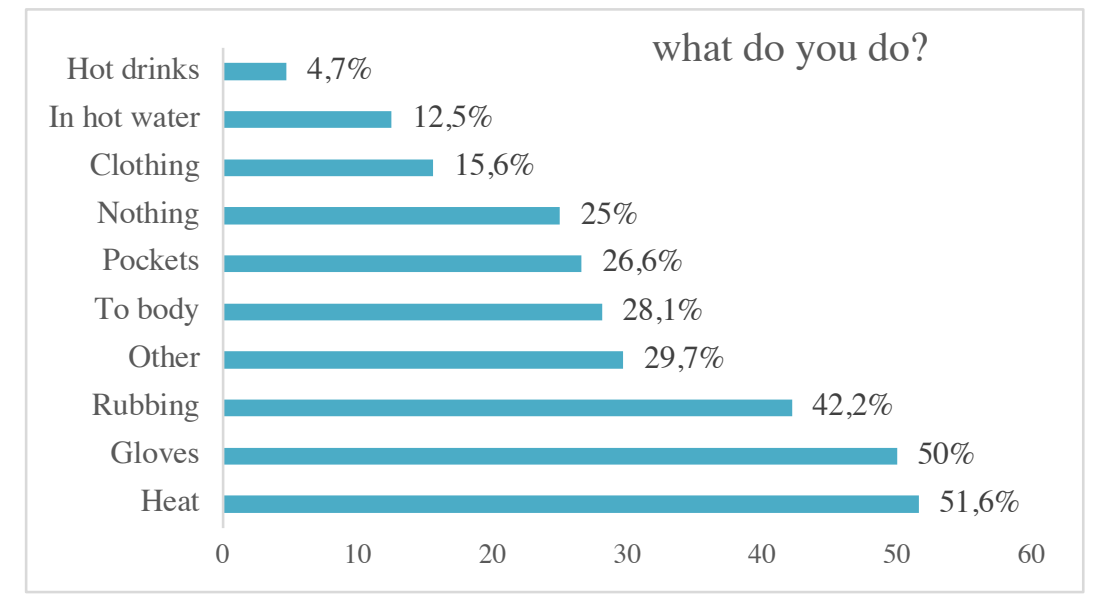

Fig. 5. What do you do in response to an RP episode? 


\subsection{Detriment of episodes}

The worst part of the episodes is grouped into 5 core topics, by combined $\%$ are in the following order 1st Inability, 2nd Other, 3rd Pain, 4th Numbness/insensitivity and 5th Time, as seen in Figure 6 \& Table 4. There are many mixed elements illustrating the complexity of the condition and the variation in personal experience, the largest Other subgroups are 3 joints at $10.9 \%$ each: embarrassment/stigma, stiffness/swelling $\&$ ulcers. Comments for Table 4 were, again like Table 2, far more detailed than Table 3 exampling how the worst parts affect patients compelling more responses.

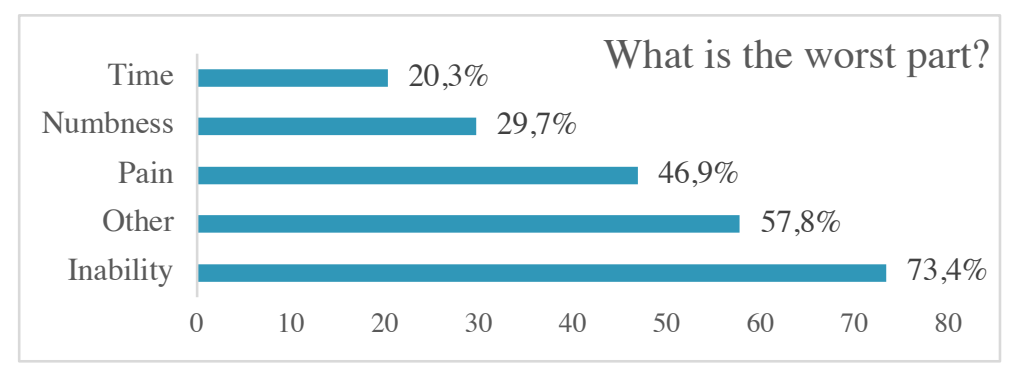

Fig. 6. What is the worst part about RP?

Table 2. Activities

\begin{tabular}{|c|c|c|}
\hline $\begin{array}{c}\text { UK } n=36 \\
\text { Number }(\%)\end{array}$ & $\begin{array}{c}\text { Portugal } n=28 \\
\text { Number }(\%)\end{array}$ & $\begin{array}{c}\text { Combined } \\
n=64\end{array}$ \\
\hline At home:27 (75\%) & At home:20 (71.4\%) & $47(73.4 \%)$ \\
\hline $\begin{array}{l}\text { "Putting make up on to go out" } \\
\text { "Knitting/ cold pins, sitting at } \\
\text { Home - it stops the rhythm of } \\
\text { knitting" } \\
\text { Subgroup: Kitchen: } 23(63.9 \%) \\
\text { [Inc. Fridge freezer \& Preparing } \\
\text { food] } \\
\text { "Cold cutlery, home" "peeling } \\
\text { potatoes etc." "handling any item } \\
\text { in the morning, kitchen" } \\
\text { Subgroup: Laundry: } 8(22.2 \%) \\
\text { "hanging out the washing, gar- } \\
\text { den" } \\
\text { "Getting undressed \& dressed" }\end{array}$ & $\begin{array}{l}\text { "In the morning when getting up, } \\
\text { either getting out of bed, the differ- } \\
\text { ence in temperature or putting on } \\
\text { hand cream" } \\
\text { Kitchen: } 15(53.6 \%) \text { : } \\
\text { "Gets attacks from being outside or } \\
\text { cutting meat" "Forced to cut veg, } \\
\text { peel veg, button clothing, kitchen } \\
\text { and laundry also problems." } \\
\text { Laundry: } 10 \text { ( } 35.7 \%) \\
\text { "Handling the clothes from the } \\
\text { washing machine" "placing clothes } \\
\text { outside to dry" }\end{array}$ & $\begin{array}{l}\text { Kitchen: } \\
38(59.4 \%) \\
\text { Laundry: } \\
18(28.1 \%)\end{array}$ \\
\hline $\begin{array}{l}\text { Travel: } 28(\mathbf{7 7 . 8 \%}) \text { [Inc. com- } \\
\text { mute/ change in environment, be- } \\
\text { tween rooms, indoor to outdoor] }\end{array}$ & Travel: $16(57.1 \%)$ & $44(68.8 \%)$ \\
\hline $\begin{array}{l}\text { "Unlocking the door, undressing, } \\
\text { picking up objects unclipping my } \\
\text { helmet. " } \\
\text { "Trying to hold onto grab rails. } \\
\text { train/bus journeys" } \\
\text { Subgroup: Driving \& walking: } \\
20(55.6 \%) \\
\text { "Opening car door, fastening car } \\
\text { seat straps " } \\
\text { "Driving, cold steering wheel" }\end{array}$ & $\begin{array}{l}\text { "Has a smart automatic car, still } \\
\text { hurts sometimes to drive but less at- } \\
\text { tacks than when walking." "It's the } \\
\text { worst on the street, with the wind, } \\
\text { all year round" } \\
\text { Driving \& walking: } 8(28.6 \%) \\
\text { "Would like to walk more but it } \\
\text { hurts her feet" }\end{array}$ & $\begin{array}{l}\text { Driving \& walking: } \\
28(43.8 \%)\end{array}$ \\
\hline
\end{tabular}


Farming: $6(16.7 \%)$

"Picking beans"

"Feeding baby calves with milk bottles"

"Watering an orchard"

Work \& computer: $10(27.8 \%)$

[Inc. teaching, seamstress, MD]

"Working, cold offices"

"As a sewer, the hardening of my fingers makes it more difficult to pick up needles and pins and small objects, fastening necklaces etc." "at work, cleaning" "working on laptop, office" "The pain and when it affects me writing, opening/ picking up things etc. it's very frustrating."

"Working out of doors \& often having to handle/ grip cold wet objects. Cold feet in boots."

\section{Every/ any -thing/ where: 10}

(27.8\%)

[Touching anything cold]

"holding anything cold. Anywhere"

"very debilitating effects all aspects of life."

Beach/ pool: 4 (11.1\%) [sea/ swimming pool]

"swimming in pool or sea. on holiday in warm locations "

Exercise: 7 (19.4\%)

"Cycling \& unclipping my helmet."

A/C \& supermarkets: 23

(63.9\%)

[\& shopping]

"payment and packing shopping"

"supermarket trolley handles"

"getting money out of purse" "air

conditioning, meetings"

Stress: 2 (5.6\%)

"stress. anywhere!" "trying to stay warm \& not get too

stressed."

Other: 22 (61.1\%)

"Walking the dog, outside"

Subgroups: Writing: 4 (11.1\%)

Sitting: 7 (19.4\%) "walking the dog, outside" "filling in this questionnaire" "sitting still, public building, church".

\author{
Farming: 2 (7.1\%) \\ [no specifics]. \\ Work \& computer: 9 (32.1\%) \\ [factory] “... used to bleed from \\ fingers when working on certain as- \\ pects within the job" \\ "The boss didn't allow the wearing \\ of gloves in work, so gloves weren't \\ worn “" \\ "Typing on the computer is very \\ difficult ... even has an ulcer" \\ "When using the walk-in fridge toes \\ can't rewarm it's difficult to walk" \\ "Chose early retirement as she \\ could no longer pick up a sewing \\ needle."
}

$8(12.5 \%)$

$19(29.7 \%)$

Every/ any -thing/ where: 5 (17.9\%)

"finds everything difficult" "In winter hands are always cold, if she touches anyone, they tell her, her hands feel cold"

Beach/ pool: 8 (28.6\%)

"Likes the beach but even in summer if she touches the water, she will get RP - white fingers"

Exercise: 4 (14.3\%)

$15(23.4 \%)$

"Riding a bike, doing exercise"

A/C \& supermarkets: 6 (21.4\%) $11(17.2 \%)$

"Has attacks when she goes to pay the baker for the weeks bread, always rushes home after" "Can't use coins "

\section{Stress: 4 (14.3\%)}

"angry \&/or stressed it shows immediately on her fingers"

\section{Other: 10 (35.7\%)}

"knitting"

Subgroups: Writing: 2 (7.1\%)

Phone: 2 (7.1\%) "Can't write when

she has white finger, this causes pain" "using mobile phone" 
Table 3. What do you do?

\begin{tabular}{|c|c|c|}
\hline $\begin{array}{c}\text { UK } n=36 \\
\text { Number }(\%)\end{array}$ & $\begin{array}{c}\text { Portugal } n=28 \\
\text { Number }(\%)\end{array}$ & Combined $n=64$ \\
\hline Rubbing: 13 (36.1\%) & Rubbing: 14 (50\%) & $27(42.2 \%)$ \\
\hline $\begin{array}{l}\text { "rub them together gently" "rub } \\
\text { fingers or blow into cupped hands" }\end{array}$ & $\begin{array}{l}\text { "rubbing the hands, get a heated } \\
\text { cloth" "rubs them, specifically } \\
\text { aiming for the blood vessels" }\end{array}$ & \\
\hline Wearing gloves: $18(50 \%)$ & Wearing gloves: $14(50 \%)$ & $32(50 \%)$ \\
\hline $\begin{array}{l}\text { "carry gloves all year round" } \\
\text { "Gloves - good quality ones" } \\
\text { "medical exam gloves" "water- } \\
\text { proof gloves" } \\
\text { ""gloves, inside and outside" } \\
\end{array}$ & $\begin{array}{l}\text { "Gets attacks with laundry dislikes } \\
\text { gloves, feels unable to func- } \\
\text { tion...Found that job difficult, but } \\
\text { finds everything difficult" }\end{array}$ & \\
\hline Heat: $24(66.7 \%)$ & Heat: $9(32.1 \%)$ & $33(51.6 \%)$ \\
\hline $\begin{array}{l}\text { "I have the central heating on con- } \\
\text { stantly" "Electric gloves and heat } \\
\text { bags to warm hands and feet" } \\
\text { "a warm fire" }\end{array}$ & $\begin{array}{l}\text { "Wood fire oven, when gets at- } \\
\text { tacks puts hands over the top of the } \\
\text { oven or to the fireplace" "Used an } \\
\text { electric 'bag' like an electric blan- } \\
\text { ket but a big pocket" }\end{array}$ & \\
\hline Nothing: $11(30.6 \%)$ & \begin{tabular}{|c|} 
Nothing: $5(17.9 \%)$ \\
\end{tabular} & $16(25 \%)$ \\
\hline $\begin{array}{l}\text { "Even when I take all preventive } \\
\text { measures, I cannot stop it occur- } \\
\text { ring" }\end{array}$ & "Couldn't do anything" & \\
\hline Clothing: $9(25 \%)$ & Clothing: 1 (3.6\%) & $10(15.6 \%)$ \\
\hline $\begin{array}{l}\text { "Try to keep warm/ layers/ wear- } \\
\text { ing warm clothes even in summer " }\end{array}$ & "Layers of clothing “ & \\
\hline Hands close to body: $11(30.6 \%)$ & Hands close to body: $7(25 \%)$ & $18(28.1 \%)$ \\
\hline $\begin{array}{l}\text { "Placing under clothing, near the } \\
\text { rest of body" "place under arms or } \\
\text { sit on hands" "put hands under } \\
\text { arms or legs (if sitting)" "under my } \\
\text { armpits or neck" }\end{array}$ & $\begin{array}{l}\text { "Summertime I put my hands un- } \\
\text { der my arms" "holding hands be- } \\
\text { tween legs" "Normally when hands } \\
\text { are cold, she puts them under her } \\
\text { armpits" }\end{array}$ & \\
\hline Hot drinks: 2 (5.6\%) & Hot drinks: 1 (3.6\%) & $3(4.7 \%)$ \\
\hline $\begin{array}{l}\text { "'Hot drinks before going out" } \\
\text { "making/holding hot drink" } \\
\end{array}$ & "Rub the hands and hold hot tea" & \\
\hline $\begin{array}{l}\text { Pockets: } 16 \text { (44.4\%) [hands in pock- } \\
\text { ets]. }\end{array}$ & Pockets: 1 (3.6\%) [hands in pockets]. & $17(26.6 \%)$ \\
\hline $\begin{array}{l}\text { "Even with gloves on I still have to } \\
\text { put in my pockets." }\end{array}$ & "Hands in pockets" & \\
\hline $\begin{array}{l}\text { Hands in hot/warm water: } 5 \\
(13.9 \%)\end{array}$ & $\begin{array}{l}\text { Hands in hot/warm water: } 3 \\
(10.7 \%)\end{array}$ & $8(12.5 \%)$ \\
\hline $\begin{array}{l}\text { "Run under warm water" "some- } \\
\text { times go and wash in warm water" } \\
\text { "rinsing under hot tap" }\end{array}$ & $\begin{array}{l}\text { "Now uses warm water." "put her } \\
\text { hands in hot water" }\end{array}$ & \\
\hline \begin{tabular}{|c|} 
Other: $15(41.7 \%)$ \\
\end{tabular} & Other: $4(14.3 \%)$ & $19(29.7 \%)$ \\
\hline $\begin{array}{l}\text { "move hands, wrists and circle } \\
\text { arms to try and improve circula- } \\
\text { tion" "shaking, rubbing, pocket" } \\
\text { "drink alcohol" }\end{array}$ & $\begin{array}{l}\text { "Uses an electric heat "pocket"" } \\
\text { (described as plug in to charge, put } \\
\text { your hands in similar to a muff, } \\
\text { made of cotton). "Avoid triggers" }\end{array}$ & \\
\hline
\end{tabular}


Table 4. What is the worst part?

\begin{tabular}{|c|c|c|}
\hline $\begin{array}{c}\text { UK } n=36 \\
\text { Number }(\%)\end{array}$ & $\begin{array}{c}\text { Portugal } n=28 \\
\text { Number }(\%)\end{array}$ & $\begin{array}{c}\text { Combined } \\
n=64\end{array}$ \\
\hline Pain: $19(52.8 \%)$ & Pain: $11(39.3 \%)$ & $30(46.9 \%)$ \\
\hline $\begin{array}{l}\text { "so painful, not wishing it on any- } \\
\text { one, people think I'm mad, all the } \\
\text { clothing, but it is what I have to } \\
\text { do." "very painful and limiting" }\end{array}$ & $\begin{array}{l}\text { "like having a tooth taken out, its } \\
\text { numb at first then later hurts a lot, } \\
\text { hurts through the middle and hands } \\
\text { feel stiff like rocks" }\end{array}$ & \\
\hline $\begin{array}{l}\text { Inability: } 28 \text { (77.8\%) [\& Incapaci- } \\
\text { tating] }\end{array}$ & Inability: 19 (67.8\%) & $47(73.4 \%)$ \\
\hline $\begin{array}{l}\text { "It is more disabling than others } \\
\text { would imagine. Whenever I go out, } \\
\text { I have to think/plan ahead, carry } \\
\text { lots of layers. I feel that it's hard to } \\
\text { dress-up for a night out, as I al- } \\
\text { ways need so many layers over } \\
\text { whatever I am wearing. I always } \\
\text { feel a mess when everybody else is } \\
\text { dressed up in evening wear." "As } \\
\text { a sewer, the hardening of my fin- } \\
\text { gers makes it more difficult to pick } \\
\text { up needles and pins and small ob- } \\
\text { jects, fastening necklaces etc." "ac- } \\
\text { tivities of daily living, opening } \\
\text { things, jars etc. doing buttons etc." } \\
\text { "to be able to go anywhere except } \\
\text { my own home when it's cold. This } \\
\text { is very limiting as I need to social- } \\
\text { ize." "I have had it for } 30 \text { years } \\
\text { and it has impacted my whole life. } \\
\text { I used to cycle, swim and ski but } \\
\text { gave that up - skiing, a long time } \\
\text { ago. " }\end{array}$ & $\begin{array}{l} \\
\text { "Precision, fine tasks, computer } \\
\text { use, drawing, writing" } \\
\text { "Has had ulcers from screwing } \\
\text { screws, had a month off work due } \\
\text { to the severity of finger no. } 3 \text {. had } \\
\text { the ulcer" } \\
\text { "Can't write with white finger, } \\
\text { this causes pain." } \\
\text { "Worked as a seamstress, her } \\
\text { hands and her feet were always } \\
\text { cold, never had pain in her work } \\
\text { but it was difficult to grab things." } \\
\text { "Works in a textiles factory cut- } \\
\text { ting, gets attacks in work, can } \\
\text { barely work, feels stressed and it } \\
\text { gets worse" } \\
\text { "... wears thin gloves, its painful, } \\
\text { makes the job difficult" } \\
\end{array}$ & \\
\hline $\begin{array}{l}\text { Time: } \mathbf{1 0}(\mathbf{2 7 . 8 \%}) \text { [Amount of time it } \\
\text { takes] }\end{array}$ & Time: 3 (10.7\%) & $13(20.1 \%)$ \\
\hline $\begin{array}{l}\text { "I cannot do anything and often } \\
\text { takes the whole day to recover" } \\
\text { "the time it all takes, pain \& people } \\
\text { waiting behind me" "I have to } \\
\text { guard against having attacks all of } \\
\text { the time." }\end{array}$ & $\begin{array}{l}\text { "it's difficult to walk, lasts about } \\
10 \text { min and is painful. Hands last } \\
\text { about } 8-10 \text { min" }\end{array}$ & \\
\hline $\begin{array}{l}\text { Numbness/ insensitivity: } 8 \\
(22.2 \%)\end{array}$ & $\begin{array}{l}\text { Numbness/ insensitivity: } 11 \\
(39.3 \%)\end{array}$ & $19(29.7 \%)$ \\
\hline $\begin{array}{l}\text { "loss of grip and sensation" "no } \\
\text { sensation in toes" }\end{array}$ & $\begin{array}{l}\text { "smashed a bottle of water because } \\
\text { her hands were so numb" }\end{array}$ & \\
\hline Other: $27(75 \%)$ & Other: $21(75 \%)$ & $48(75 \%)$ \\
\hline $\begin{array}{l}\text { "stiff fingers need to find a warm } \\
\text { place for } 30 \text { mins" "trying to pre- } \\
\text { vent it happening even when I take } \\
\text { all preventive measures, I cannot } \\
\text { stop it occurring. I know when it } \\
\text { will happen and can't stop it and } \\
\text { that is frustrating." "it was embar- } \\
\text { rassing" "sheer frustration" "to } \\
\text { keep the ulcers at bay if possible } \\
\text { but doesn't always work " }\end{array}$ & $\begin{array}{l}\text { "to stay uninjured" "When toes are } \\
\text { red gets very itchy" "She really } \\
\text { hates when people stare, it's worse } \\
\text { than the pain that she feels she can } \\
\text { cope with" } \\
\text { "In winter the hands are always } \\
\text { cold, if she touches anyone, they } \\
\text { tell her, her hands feel cold" "get- } \\
\text { ting ulcers from working" }\end{array}$ & $\begin{array}{c}\text { Stiffness/ swelling: } \\
7(10.9 \%) \\
\text { Stigma: } \\
7(10.9 \%) \\
\text { Ulcers: } \\
7(10.9 \%)\end{array}$ \\
\hline
\end{tabular}




\section{Discussion}

The study aims at evaluating the Raynaud's Phenomenon Quotidian Quality of Life impact (Q QoL), gaining a picture of daily tasks in order to move towards an alleviation outcome from a design research perspective. The focus is for a design research solution, not clinical classification or diagnosis. The objective of the activities questions was to understand their triggers, what is bothersome for the participant and when. The aim here, from a design perspective, is to understand where the patients need is most significant and target this for developing solutions.

The collective findings reveal 3 central interconnected outcomes; First that RP effects all aspects of wellbeing; physical, mental and social. Second a criterion, Design Specification (DS), outlining detailed attributes that are used as a checklist of requirements when designing and developing the concept. Third, 3 core needs \& 1 underlying aspect for RP hands \& fingers. Figure 7 visualizes the outcomes with an example.

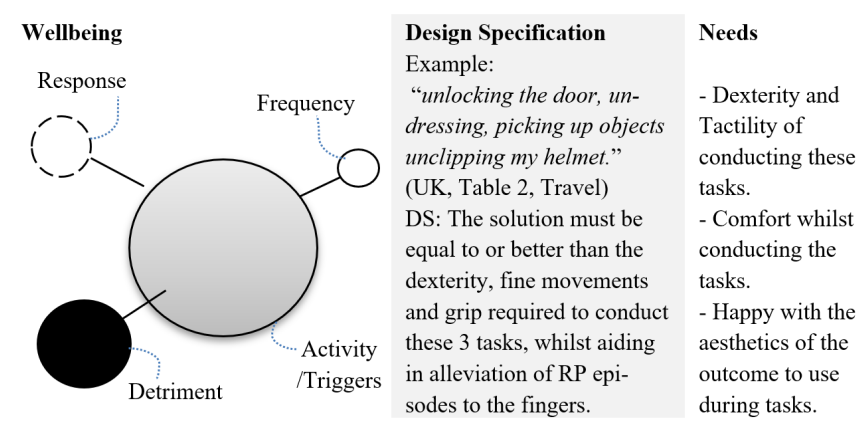

Fig. 7. Questionnaires visualised formed into diagram of the 3 core outcomes.

All aspects of wellbeing can be found in the quotes and topics of Tables $2 \& 4$. In Figure 7 tables (T) are referred to by the following names; T2, Activity /Triggers; Figure 4 Frequency, T3 Response, T4 Detriment. The DS through activities, any one of the activities/tasks listed must be addressed and completable with the solution, Figure 7 gives an example of this. Furthermore, the solution should be useable by patients including those with impeded motion of the hand from stiffness, swelling or numbness. Figure 8 comes from an analysis of the DS revealing 3 core needs identified: Dexterity, Tactility and Comfort and 1 underlying aspect: Aesthetics. Aesthetics in the choice to 'look normal' or as if nothing is wrong. From the 3 needs activity examples show how they relate back to the questionnaire; including Tactility $>$ physical contact i.e. touching a friend or family's arm. This analysis is subjective on the part of the investigator/ first author, having spent time with patients, observed them and within this questionnaire, with their own words, formulation of analysis and categorisation. The likelihood is another researcher may come to different findings. 


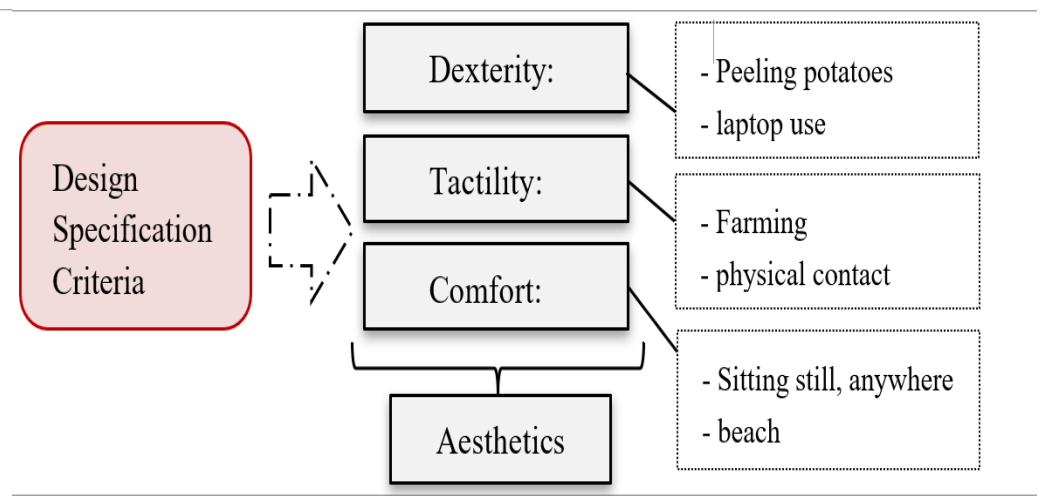

Fig. 8. Analysis of findings, with examples of activities relating to the 3 identified needs.

Regarding RP patients experience and stories, there are several examples from clinical and RP communities; Pauling et al. conducted a multinational study utilizing focus groups for patient-reported outcomes [11], Maundrell \& Proudman [1] and Dinsdale \& Herrick [13] include patient case studies, SRUK webpage has a compilation of 'personal stories' [14]. The following is a brief overview of publications and media on: Single case studies, Diary card systems, Medical journal case studies, SRUK personal stories and Pauling et al.'s multinational study where impact and QoL of RP are incorporated. Single case studies [1,13] give further details such as Agbor et al. [15] which assesses the case of a farmer in Cameroon requiring amputation and going through diagnosis of SRP, detailing history with a feeling of 'pins and needles' aggravated by cold, mainly weather and cold-water immersion of hands. Diary card systems and scoring [16] have been used with the aim to quantify RP attacks and [16] also covers a comprehensive review on non-drug approaches to treating RP, which includes discussion on QoL and RP. The research of $[1,13,15,16]$ show useful insights into life with $\mathrm{RP}$, yet contain limited information as to the details of quotidian life experience, explaining key issues and occupation but rarely specific activities and where they take place, as for many of the clinical publication's details of QoL are not part of their intended purpose. SRUK personal stories [14] contain some useful details, they coincide with the findings from the questionnaires here e.g. hanging washing from Claire and Lewis's story \& struggling with public transport from Amy's story, however there are only a few stories, the 64 participants in this study give a wider field of quotidian life RP experience. Pauling et al.'s multinational study [8] by focus groups (40 participants, 4 locations UK \& US and 6 sessions) contains much more detail and the results have many similarities and details that coincide, the 7 themes identified of SSc-RP are also clearly seen within this study: "physical symptoms, emotional impact, triggers and exacerbating factors, constant vigilance and self-management, impact on daily life, uncertainty and adaption", Adaption is less obvious though can be recognised in tables 2 and 4, e.g. table 4, inability, UK; "It is more disabling than others would imagine. Whenever I go out, I have to think/plan ahead, carry lots of layers. I feel that it's hard to dress-up for a night out, as I always need so many layers over whatever I am wearing.”. Pauling et al.'s and this study show different perspectives \& aims over a shared topic space of patient RP experience. 
The field of design research centred on aging populations, specifically long-term conditions that progress slowly, observes removing aspects of independence. This is a predominant feature in this $R P$ needs research problem, and fits into the key challenges in design and healthcare set out by Tsekleves \& Cooper [17]. In the difficulties with activities and the long-term nature of RP independence in daily life activities is a factor. This challenge contains design and social aesthetic implications as described by Kwakkenbos et al., [16] a major problem with using gloves and the hands as they are difficult to hide, usually exposed and for RP can feel uncomfortable/stigmatised, particularly in summer. Therefore, needing the Design Specification to tackle aesthetics and functionality. Quotidian activities have been utilised in other health studies, Priana et al., [18] termed this Activity Daily Living and used User Centred Design (UCD) \& User Experience (UX) to develop stroke communication boards into a smart phone/mobile application from observing patients and conducting questionnaires. Dermawi et al., also highlights the UCD approach in regard to deaf people [19]. UX is used in modernising the need and improving medical strategies, in Priana et al.'s case: communication with patients. PCD holds similarities to Patient Oriented design which looks at empowering the patient to be more involved in their own condition [20]. UCD and HCD [21] are very similar in methodological approach, PCD was chosen here as from the literature the focus is more appropriate $[9,10]$. Patient-centred design offers a process to improve individual and community health over a wide spectrum of problems. [9]. The first key finding is wellbeing; within RP a previous QoL questionnaire looked at mental and physical health, quantifying the comparison between PRP and SRP, Fábián et al. [22]. PRP and SRP were not separated here, in further research if there is a requirement for multiple solutions dependants on RP severity, research should take into account these differences. Raynaud's phenomenon has not previously been assessed for a design outcome from a design research perspective. This paper takes the PCD underlying method focusing on the patient using DS. Culminating in 3 key findings: A) RP effects all aspects of wellbeing, B) DS by activities \& C) 3 core needs and 1 underlying aspect focusing on hands \& fingers.

\section{Conclusion}

Many quotidian activities trigger RP episodes, some holding a greater impact to the patient than others. For many the pain is not the worst part, the worst part is the hindrance of function around all wellbeing aspects; physically, socially and mentally. Any viable solution must adhere to the needs identified through the DS that predominantly culminate in maintaining: Dexterity, Tactility and Comfort with the fundamental aspect of aesthetics', to 'look/feel normal'. The ability to use the hands and fingers is crucial whilst the solution is in use with minimal, if any, side effects. From this research a further study has been designed to take a deeper look at appropriate solutions. 


\section{Acknowledgement}

Isobel Taylor is grateful to The Portuguese Foundation for Science and Technology (FCT) and the Doctoral Program in Design of the University of Porto for her PhD scholarship ref: $\mathrm{PD} / \mathrm{BD} / 128020 / 2016$. The authors gratefully acknowledge the funding of project LAETA -UIDB/EMS/50022/2020. Special thanks to all the patients who took part your help is indispensable. Thanks to SRUK and Central Hospital Universitario Porto (CHUP) staff, C. Veiga MD, Design director H. Alvelos for their support.

\section{$7 \quad$ References}

[1] Maundrell, A., Proudman, S., M. (2015) Epidemiology of Raynaud's Phenomenon. In: Wigley FM, Herrick AL and Flavahan NA (eds) Raynaud's phenomenon: a guide to pathogenesis and treatment. New York: Springer, 2015, pp. 21-35. https://doi.org/10.1007/978-14939-1526-2_3

[2] Hughes, M. \& Herrick, A, L., (2016) Raynaud's phenomenon, Best Practice \& Research Clinical Rheumatology. 1-21. https://doi.org/10.1016/j.berh.2016.04.001

[3] Maricq, H, R., Carpentier, P, H., Weinrich, M, C., Keil, J, E., Franco, A., Drouet, P., Ponçot, O, C., Maines, M, V., (1993) Geographic variation in the prevalence of Raynaud's phenomnenon: Charleston, SC, USA, vs Tarentaise, Savoie, France. J Rheumatol 20(1):70-6.

[4] Purdie, G., Harrison, A., Purdie, D., (2009) Prevalence of Raynayd's phenomenon in the adult New Zealand population. N Z Med J. 20;122(1306):55-62.

[5] Carpentier, P, H., Satger, B., Poensin, D, Maricq, H, R., (2006) Incidence and natural history of Raynaud phenomenon: a long-term follow-up (14 years) of a random sample from the general population. J Vasc Surg 44:1023-8. https://doi.org/10.1016/j.jvs.2006.07. $\underline{037}$

[6] Herrick, A., L. (2019) Raynaud's phenomenon. Review, Journal of Scleroderma and related disorders: $1-13$

[7] Herrick, A, L., (2009) A local approach to Raynaud phenomenon. Nature Reviews Rheumatology 5, 246-247.

[8] Pauling, J. D., Domsic, R. T., Saketkoo, L. A., Almeida, C. , Withey, J. , Jay, H. , Frech, T. M., Ingegnoli, F. , Dures, E. , Robson, J. , McHugh, N. J., Herrick, A. L., Matucci-Cerinic, M. , Khanna, D. and Hewlett, S. (2018), Multinational Qualitative Research Study Exploring the Patient Experience of Raynaud's Phenomenon in Systemic Sclerosis. Arthritis Care Res, 70: 1373-1384. https://doi.org/10.1002/acr.23475

[9] Ryan, K., LaBat, K. (2009) Addressing the challenges of patient-centred design. AMJ, 1,13,204-210. DOI 10.4066/AMJ.2009.101. https://doi.org/10.4066/amj.2009.101

[10] Mannonen, P., Kaipo, J., Nieminen, M., P. (2017) Patient-Centred Design of Healthcare Services: Meaningful Events as Basis for Patient Experiences of Families. Studies in Health technology and informatics. IOS Press. 234: 206-210.

[11] Milton, A. \& Rodgers, P (2013) Research Methods for Product Design. Laurence King publishing Ltd, London.

[12] Sruk.co.uk (2019) home page. [online] Available at: https://www.sruk.co.uk/[Accessed 1 Oct. 2019].

[13] Dinsdale, G., Herrick, A, L., (2014) Vascular diagnostics for Raynaud's phenomenon, journal of Vascular Diagnostics. 2014: 2 127-139. https://doi.org/10.2147/jvd.s52943 
[14] Sruk.co.uk (2019) personal stories. [online] Available at: https://www.sruk.co.uk/find-support/personal-stories/[Accessed 1 Oct. 2019].

[15] Agbor, V. N., Njim, T., \& Aminde, L. N. (2016). Difficulties in diagnosis and treatment of severe secondary Raynaud's phenomenon in a Cameroonian woman: a case report. Journal of medical case reports, 10(1), 356. https://doi.org/10.1186/s13256-016-1142-x

[16] Kwakkenbos L and Thombs BD. Non-drug approaches to treating Raynaud's phenomenon. In: Wigley FM, Herrick AL and Flavahan NA (eds) Raynaud's phenomenon: a guide to pathogenesis and treatment. New York: Springer, 2015, pp. 299-313. https://doi.org/10.1007/978-1-4939-1526-2 19

[17] Tsekleves, E. \& Cooper, R. (2017) Emerging Trends and the way Forward in Design in Healthcare: An Expert's Perspective, The Design Journal, 20:sup1, S2258-S2272. https://doi.org/10.1080/14606925.2017.1352742

[18] Priana, A, J., Tolle, H., Arisetijono, E., (2018) User Experience Design of Stroke Patient Communications Using Mobile Finger (MOFI) Communication Board with User Center Design Approach. International Journal of Interactive Mobile Technologies, iJIM: 12; 2. https://doi.org/10.3991/ijim.v12i2.7937

[19] Dermawi, R., Tolle, H., Aknuranda, I. (2018) Design and Usability Evaluation of Communication Board for Deaf People with User-Centred Design Approach. iJIM- v.12, No.2. https://doi.org/10.3991/ijim.v12i2.8100

[20] Rosado, L., Vasconcelos, M., J., Ferreira, M. (2013) A Mobile-Based Prototype for Skin Lesion Analysis: Towards a Patient-Oriented Design Approach. iJOE, 9: 8, pp 27-29. https://doi.org/10.3991/ijoe.v9is8.3372

[21] Giacomin, J. (2014) What Is Human Centred Design? The Design Journal, 17:4, 606-623.

[22] Fábián, B., Fábián, A, K., Bugán, A., Csiki, Z. (2019) Comparison of mental and physical health between patients with primary and secondary Raynaud's phenomenon Category: Article. Journal of Psychosomatic Research. 116: 6-9. https://doi.org/10.1016/j.jpsychores.2018.11.001

\section{Authors}

Isobel Taylor is a $\mathrm{PhD}$ student in Design at the Faculty of Fine Arts at the University of Porto (FBAUP) and holds an MRes in Digital Media (2010) from Newcastle University. Multidisciplinary design researcher focused on medical devices, co-founder of SenseIV.

Ivone Silva MD holds a PhD (2015) Raynaud's phenomenon Risk Factors of Digital Ulcers in Systemic Sclerosis patients from ICBAS University of Porto. She is currently Associate Professor at ICBAS, an Integrated PhD Researcher of the unit for multidisciplinary research in biomedicine, and Vascular Consultant in Centro Hospitalar do Porto.

Susana Barreto holds a PhD (2008) and PostDoc (2010) from Central Saint Martins and an MA in Information Design (1996) from De Montfort University. A design researcher and educator focusing on the cultural implications of visual communication, visual methodologies and visual ethics, Faculdade de Belas Artes da Universidade do Porto (FBAUP).

César Soares holds a Master Degree in Mechanical Engineering from the Faculdade de Engenharia da Universidade do Porto (FEUP, 2017), specialization in automation. He is currently researcher at FEUP, working in computer design and simulation. 
Joaquim Mendes holds a PhD in Industrial Electronics from Universidade do Minho (2003), a Master in Computer \& Industrial Engineering, and a degree in Mechanical Engineering. He is currently Associate Professor at Faculdade de Engenharia da Universidade do Porto (Portugal) and researcher at INEGI - Institute of Science and Innovation in Mechanical and Industrial Engineering. Email: jgabriel@fe.up.pt

Article submitted 2020-02-29. Resubmitted 2020-03-27. Final acceptance 2020-03-28. Final version published as submitted by the authors. 